University of Wollongong

Research Online

Australian Institute for Innovative Materials -

Papers

Australian Institute for Innovative Materials

$1-1-2017$

\title{
High performance carbon-coated hollow Ni12P5 nanocrystals decorated on GNS as advanced anodes for lithium and sodium storage
}

\author{
Huinan Guo \\ Nankai University \\ Chengcheng Chen \\ Nankai University \\ Kai Chen \\ Nankai University \\ Haichao Cai \\ Nankai University \\ Xiaoya Chang \\ Nankai University
}

See next page for additional authors

Follow this and additional works at: https://ro.uow.edu.au/aiimpapers

Part of the Engineering Commons, and the Physical Sciences and Mathematics Commons

Research Online is the open access institutional repository for the University of Wollongong. For further information contact the UOW Library: research-pubs@uow.edu.au 


\title{
High performance carbon-coated hollow Ni12P5 nanocrystals decorated on GNS as advanced anodes for lithium and sodium storage
}

\author{
Abstract \\ Transition-metal phosphides have been considered as promising anode materials for rechargeable \\ secondary batteries owing to their low cost and high capacity. However, low electronic conductivity and \\ poor stability limit their further development. Herein, we have designed a template-free refluxing method \\ for synthesizing tailored carbon-coated hollow Ni 12 P 5 nanocrystals in situ grown on reduced graphene \\ oxide nanosheets (denoted as Ni 12 P 5 @C/GNS). The hollow structure can accommodate volume \\ expansion and shorten the ion transfer path. The GNS loading and carbon shell can efficiently prevent Ni \\ 12 P 5 from aggregating and improve the electronic conductivity. As an anode of Li-ion batteries (LIBs), \\ the hollow Ni 12 P 5 @C/GNS composite displays an excellent discharge specific capacity of $900 \mathrm{~mA} \mathrm{~h} \mathrm{~g}$ \\ -1 at a current density of $100 \mathrm{~mA} \mathrm{g-1}$ after 100 cycles and outstanding rate capability. Furthermore, it also \\ shows a good Na storage capability with a reversible capacity of $235 \mathrm{~mA} \mathrm{~h} \mathrm{~g} \mathrm{-1} \mathrm{at} 100 \mathrm{~mA} \mathrm{~g} \mathrm{-1.}$ \\ Therefore, our work demonstrates that this hollow Ni 12 P 5 @C/GNS composite has great potential for \\ Li/Na storage.

\section{Disciplines} \\ Engineering | Physical Sciences and Mathematics

\section{Publication Details} \\ Guo, H., Chen, C., Chen, K., Cai, H., Chang, X., Liu, S., Li, W., Wang, Y. \& Wang, C. (2017). High performance \\ carbon-coated hollow Ni12P5 nanocrystals decorated on GNS as advanced anodes for lithium and \\ sodium storage. Journal of Materials Chemistry A, 5 (42), 22316-22324.
}

\section{Authors}

Huinan Guo, Chengcheng Chen, Kai Chen, Haichao Cai, Xiaoya Chang, Song Liu, Weiqin Li, Yijing Wang, and Caiyun Wang 


\section{Journal of Materials Chemistry A}

PAPER

\section{High performance carbon-coated hollow $\mathrm{Ni}_{12} \mathrm{P}_{5}$ nanocrystals decorated on GNS as advanced anodes for lithium and sodium storage $\dagger$}

Received 00th January 20xx, Accepted 00th January 20xx

DOI: $10.1039 / x 0 x \times 00000 x$

www.rsc.org/

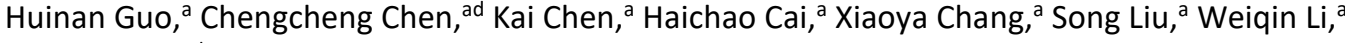 \\ Yijing Wang*ab and Caiyun Wang*c
}

\section{Introduction}

Rechargeable secondary batteries are one of the most important energy storage technologies recently. ${ }^{1-3}$ LIBs have occupied dominant position of portable electronic devices for their high operating voltage, high energy density and limited self-discharging. ${ }^{4-9}$ Besides, sodium-ion batteries (SIBs) are expected to be broadly applied to large energy storage equipment, ${ }^{10-14}$ owing to low cost and natural abundance of sodium sources. ${ }^{15,16}$ However, the commercial anode materials hardly show satisfied performances in both $\mathrm{Li} / \mathrm{Na}$ storage systems, due to the worse sluggish kinetics of sodium than that of lithium. ${ }^{17,18}$ Therefore, it is urgent to search for advanced anode materials in terms of high capacity, long cycle life and superior rate capability for both LIBs and SIBs. ${ }^{19,20}$

Transition-metal phosphides (TMPs) have been applied to several fields, especially in electrocatalysis and photocatalysis. ${ }^{21-23}$ Nevertheless, their applications as anode materials are not fully developed. Conversion type TMPs are rising anode materials for rechargeable secondary batteries in

a. Key Laboratory of Advanced Energy Materials Chemistry (Ministry of Education) College of Chemistry, Nankai University, Tianjin 300071, China.

b. Collaborative Innovation Center of Chemical Science and Engineering, College of Chemistry, Nankai University, Tianjin 300071, China. E-mail: wangyj@nankai.edu.cn.

-Intelligent Polymer Research Institute, ARC Centre of Excellence for Electromaterials Science, University of Wollongong, Wollongong, NSW 2500, Australia.E-mail: caiyun@uow.edu.au.

d. China Electronic Product Reliability and Environmental Testing Research Institute (CEPREI), Guangzhou 510610, China. + Electronic Supplementary Information (ESI) available. See DOI: 10.1039/x0xx00000x recent years. ${ }^{24-28}$ As anode materials for lithium/sodium ion batteries, based on the reversible reaction between phosphorus and $\mathrm{Li} / \mathrm{Na}\left(\mathrm{Li}_{3} \mathrm{P} / \mathrm{Na}_{3} \mathrm{P}\right)$, TMPs display high specific capacity (up to $1800 \mathrm{mAh} \mathrm{g}^{-1}$ ), $, 29,30$ low operation potential, metallic feature as well as good thermal stability. However, the large volume expansion and poor electronic conductivity of TMPs seriously limit the kinetics property and cycling stability. Facing those similar defects, Lou's group ${ }^{31}$ prepared the tailored hollow structure aiming to buffer the substantial volume change and boost the electrochemical performances. This demonstrates the hollow structure can significantly accommodate pulverization by restricting volume expansion. Additionally, Mai and co-works ${ }^{32}$ synthesized novel layered $\mathrm{Li}_{3} \mathrm{~V}_{2}\left(\mathrm{PO}_{4}\right)_{3}$, in which the LVP layers were uniformly alternated with reduced graphene oxide nanosheets to provide effective electron transport. The rate capacities of prepared $\mathrm{Li}_{3} \mathrm{~V}_{2}\left(\mathrm{PO}_{4}\right)_{3} / \mathrm{rGO} \& \mathrm{C}$ are better than most of the state-of-the-art reported results. Thus, it is interesting and worth designing the hollow nanocrystal, and combining with carbon materials to improve the electrochemical performances of $\mathrm{Ni}_{12} \mathrm{P}_{5}$.

On the other hand, the synthesis methods of TMPs are usually defective. Generally speaking, there are two primary routes to prepare TMPs. High energy mechanical milling is simple, however, the products of this method are always without hollow morphology. ${ }^{33-35}$ Another way is a solid reaction using hypophosphites $\left(\mathrm{NH}_{4} \mathrm{H}_{2} \mathrm{PO}_{2}\right.$ and $\left.\mathrm{NaH}_{2} \mathrm{PO}_{2}\right)$ as the $\mathrm{P}$ source. This process releases very flammable and poisonous $\mathrm{PH}_{3}$ gas. ${ }^{36-}$ 37 Hence, designing a facile and low toxic method for synthesis of TMPs is not only urgent, but still remains challenging. 
Herein, we firstly report a novel hollow structure of carboncoated $\mathrm{Ni}_{12} \mathrm{P}_{5}$ nanocrystals supported on reduced graphene oxide nanosheets via a simple refluxing method without any templates and surfactants, as high performance anodes for LIBs and SIBs. This pathway is facile and effective. During the synthesis, the phosphorus source is consumed in situ without hazardous gases escape. Meanwhile, the $\mathrm{Ni}_{12} \mathrm{P}_{5} @ \mathrm{C} / \mathrm{GNS}$ has endowed with three merits of targeted samples: (i) The hollow $\mathrm{Ni}_{12} \mathrm{P}_{5} @ \mathrm{C}$ with average small size of $35 \mathrm{~nm}$ effectively shortens ions/electrons transport paths and facilitates the reaction kinetics; (ii) Hollow structure and carbon shell can buffer volume expansion wonderfully; (iii) The GNS prevent aggregation and provide an electric net between grains. As expected, when measured as an anode material for LIBs, the tailored $\mathrm{Ni}_{12} \mathrm{P}_{5} @ \mathrm{C} / \mathrm{GNS}$ electrode shows a high reversible capacity of $900 \mathrm{mAh} \mathrm{g}^{-1}$ at a current density of $100 \mathrm{~mA} \mathrm{~g}^{-1}$ after 100 cycles, and excellent rate capability of discharge special capabilities of 702.2, 644.1, 566.5, 482.8, 423.2 and 905.9 mAh $\mathrm{g}^{-1}$ at $100,200,500,1000,2000$ and $100 \mathrm{~mA} \mathrm{~g}^{-1}$, respectively. We also adopt this material as an anode of SIBs for the first time, which delivers excellent performance with reversible capacity of $235 \mathrm{mAh} \mathrm{g}^{-1}$ at $100 \mathrm{~mA} \mathrm{~g}{ }^{-1}$. Therefore, $\mathrm{Ni}_{12} \mathrm{P}_{5} @ \mathrm{C} / \mathrm{GNS}$ composite is a promising anode material with high capacities and good rate capacities for LIBs and SIBs.

\section{Experimental Section}

\subsection{Chemicals}

Nickel (II) acetate tetrahydrate (AR) was purchased from Tianjin Guangfu Fine Chemical Research Institute and triphenylphosphide (TPP) was from Alfa Aesar. Oleylamine (OLA) was purchased from J\&K. All regents were used as received without further purification.

\subsection{Synthesis of reduced graphene oxide}

Graphene oxide was prepared following the modified Hummers' approach, ${ }^{38}$ then reduced by $\mathrm{H}_{2}(5 \%) / \operatorname{Ar}$ gas.

\subsection{Synthesis of $\mathrm{Ni}_{12} \mathrm{P}_{5}$ /GNS}

The $\mathrm{Ni}_{12} \mathrm{P}_{5}$ was synthesized using a facile refluxing condensation method. Briefly, $1 \mathrm{mmol} \mathrm{Ni(Ac})_{2} \cdot 4 \mathrm{H}_{2} \mathrm{O}(0.5 \mathrm{~g})$ was dispersed in $30 \mathrm{mmol}$ OLA ( $8 \mathrm{~g}$ ) in a $100 \mathrm{~mL}$ three-neck flask. The flask was heated by a heating panel magnetically stirred under Ar flow. The mixture solution was heated to $120^{\circ} \mathrm{C}$ until all Ni(Ac) $)_{2} \cdot 4 \mathrm{H}_{2} \mathrm{O}$ was dissolved and the solution turned into green. Then $10 \mathrm{mmol}$ TPP ( $2.6 \mathrm{~g})$ and a certain amount of GNS was added into the solution. The growth solution was heating to $270{ }^{\circ} \mathrm{C}$ and kept at this temperature for $30 \mathrm{~min}$. Then the solution was naturally cooled to ambient temperature. The black precipitate was isolated and washed three times with the mixture of hexane and ethanol by centrifugation. Finally, the products were dried at $80^{\circ} \mathrm{C}$ under vacuum for further characterization.

\subsection{Synthesis of $\mathrm{Ni}_{12} \mathrm{P}_{5} @ \mathrm{C} / \mathrm{GNS}$}

In a typical transformation process, the as-prepared $\mathrm{Ni}_{12} \mathrm{P}_{5} / \mathrm{GNS}$ was annealed at $450^{\circ} \mathrm{C}$ in a $\mathrm{H}_{2}(5 \%) / \mathrm{Ar}$ atmosphere for $30 \mathrm{~min}$.

\subsection{Characterization}

The products were characterized by X-ray diffractometry using a Rigaku MiniFlexll diffractometer equipped with the $\mathrm{Cu} \mathrm{Ka}$ radiation $\left(\lambda=1.54178 \AA\right.$ ) at a scan rate of $4^{\circ} \mathrm{min}^{-1}$. Raman measurement was recorded on an Invia/Reflrx Lasser MicroRaman spectroscope (Horiba Jobin Yvon, Franch). The XPS spectra were collected by a VG Scientic ESCALAB 2201XL System equipped with a monochromatic Al Ka source. The weight percentage of carbon was characterized by elemental analysis (EA, Thermal Conductivity Detector, Elemental vario E cube). Inductively coupled plasma-atomic emission spectroscopy (ICPAES) was performed on a PerkinElmer Optima 8300 instrument. Field-emission scanning electron microscopy (SEM) measurements were performed on a JEOL JSM-7500F (5 kV). Transmission electron microscopy (TEM) studies were conducted on a FEI Philips Tecnai electron microscope at an operating voltage of $200 \mathrm{kV}$.

\subsection{Electrochemical measurements.}

Half cells were carried out in standard CR2032 coin-type model cells, with $\mathrm{Li} / \mathrm{Na}$ foil as the counter and reference electrode. The working electrode was prepared by mixing $\mathrm{Ni}_{12} \mathrm{P}_{5} @ \mathrm{C} / \mathrm{GNS}$ powder, super $\mathrm{P}$ and polyvinylidene fluoride (PVDF) with a weight ratio of $7: 2: 1$. Then the mixture was ground in a mortar with $\mathrm{N}$-methyl-2-pyrrolidone (NMP) as solvent for making slurry and pasted on pure copper foil (99\%). The average mass loading of the active materials with the film was about $0.98 \mathrm{mg} \mathrm{cm}^{-2}$. For lithium ion battery, the electrolyte was $1 \mathrm{M} \mathrm{LiPF}_{6}$ in ethylene carbonate $(E C) /$ diethyl carbonate (DEC) (1:1 by volume ratio). The polypropylene film (Cellgard 2400) was used as the separator. For sodium ion battery, the electrolyte was $0.1 \mathrm{M}$ $\mathrm{NaClO}_{4}$ in diethylene glycol dimethyl ether (DEG-DME) with addition of $5 \%$ fluoroethylene carbonate (FEC). The glass fiber was used as the separator. The battery tests were assembled in an Ar-filled glovebox $\left(\mathrm{H}_{2} \mathrm{O}, \mathrm{O}_{2}<1 \mathrm{ppm}\right.$, Mikrouna). Cyclic performances were recorded on a CHI660E electrochemical station at a scan rate of $0.2 \mathrm{mV} \mathrm{s}^{-1}$ from 0.1 to $3 \mathrm{~V}$. Galvanostatic charging and discharging tests were performed using a LANDCT2001A instrument.

The electrochemical performances of full cells were also measured using a two electrode coin-type cell (CR2032). To prepare the positive electrode, a mixture of $\mathrm{LiCoO}_{2}$, Super $\mathrm{P}$ and PVDF at a weight ratio of 7:2:1 were dispersed in NMP solvent and ground thoroughly into a slurry, then pasted on aluminum foil. After being dried at $80{ }^{\circ} \mathrm{C}$, the aluminum foil with active materials was cut into small rounds for battery cathode. The negative electrode of $\mathrm{Ni}_{12} \mathrm{P}_{5} @ \mathrm{C} / \mathrm{GNS}$ was prepared by the same method. For assembling full cells, the mass ratio of cathode and anode was 16:1. The excess cathode was aimed to ensure the $\mathrm{Ni}_{12} \mathrm{P}_{5} @ \mathrm{C} / \mathrm{GNS}$ anode react thoroughly.

\section{Results and Discussion}

3.1 Structural and morphology characterization 


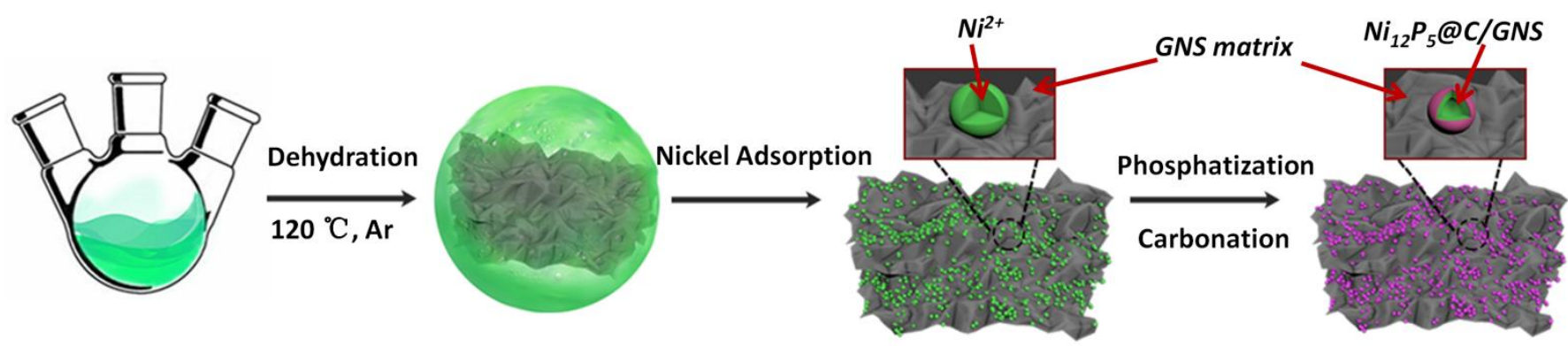

Scheme 1. Schematic illustration showing the formation preparation of $\mathrm{Ni}_{12} \mathrm{P}_{5} @ \mathrm{C} / \mathrm{GNS}$ composite.
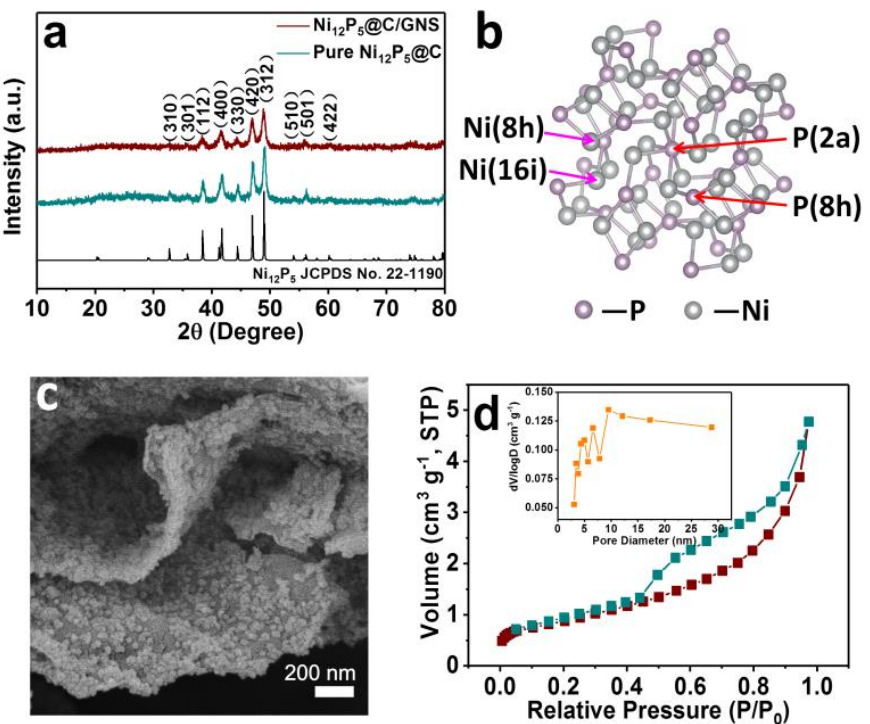

Fig. 1 (a) X-ray diffraction of pure $\mathrm{Ni}_{12} \mathrm{P}_{5} @ \mathrm{C}$ and $\mathrm{Ni}_{12} \mathrm{P}_{5} @ \mathrm{C} / \mathrm{GNS}$. (b) Structure image of $\mathrm{Ni}_{12} \mathrm{P}_{5}$ nanocrystals. (c) SEM image of $\mathrm{Ni}_{12} \mathrm{P}_{5} @ C / G N S$ composite. (d) Nitrogen absorption/desorption isotherm of $\mathrm{Ni}_{12} \mathrm{P}_{5} @ \mathrm{C} / \mathrm{GNS}$ (wine: nitrogen adsorption curve; dark cyan: nitrogen desorption curve) and pore diameter distribution (inset).

We employ GNS as an assistant agent to build hollow $\mathrm{Ni}_{12} \mathrm{P}_{5}$ nanocrystals through a facile template-free refluxing method (Scheme 1). The XRD patterns confirm the $\mathrm{Ni}_{12} \mathrm{P}_{5} @ \mathrm{C} / \mathrm{GNS}$, pure $\mathrm{Ni}_{12} \mathrm{P}_{5} @ \mathrm{C}$ and GNS are pure phase displayed in Fig. $1 \mathrm{a}$ and $\mathrm{S} 1 \uparrow$. The products fully correspond to tetragonal unit cell ( $a=8.464 \AA$, $c=5.070 \AA$, JCPDS card No. 22-1190) with the $14 / \mathrm{m}$ space group. In this structure (Fig. 1b), $\mathrm{Ni}$ atoms occupy $16 \mathrm{i}$ and $8 \mathrm{~h}$ sites connected with two $P$ atoms. While there are two kind of $P$ atoms, which reside in the 2 a sites connected with eight $\mathrm{Ni}$ and $8 \mathrm{~h}$ sites connected with four $\mathrm{Ni}$, respectively. SEM images (Fig. $\mathrm{S} 2 \dagger$ ) clearly show the sheet-like structure of GNS and nanocrystal structure of pure $\mathrm{Ni}_{12} \mathrm{P}_{5} @ \mathrm{C}$. Fig. S2b $\dagger$ displays the serious aggregation $\mathrm{Ni}_{12} \mathrm{P}_{5} @ \mathrm{C}$ without GNS. Fig. 1c exhibits the SEM image of $\mathrm{Ni}_{12} \mathrm{P}_{5} @ \mathrm{C} / \mathrm{GNS}$ composite. Notably, $\mathrm{Ni}_{12} \mathrm{P}_{5} @ \mathrm{C}$ nanocrystals with uniform size are homogeneously dispersed on the surface of GNS. In addition, compositional information

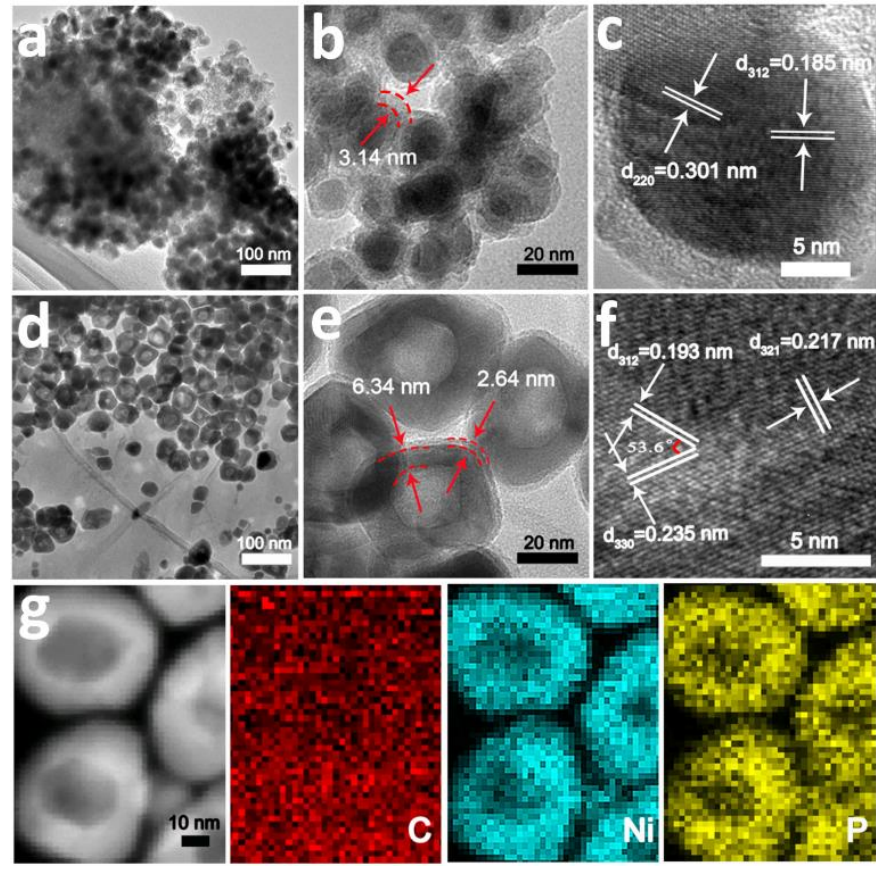

Fig. 2 Low- and high-resolution TEM images of products. (a-c) Pure $\mathrm{Ni}_{12} \mathrm{P}_{5} @ \mathrm{C}$ nanocrystals and (d-f) $\mathrm{Ni}_{12} \mathrm{P}_{5} @ \mathrm{C} / \mathrm{GNS}$ composite. (g) Elemental mapping images of $\mathrm{Ni}_{12} \mathrm{P}_{5} @ \mathrm{C} / \mathrm{GNS}$, involving original TEM image, carbon, nickel and phosphorous elements.

is determined by energy-dispersive spectrum (EDS, Fig. S3 $\uparrow$ ). The atomic ratio of $\mathrm{Ni}$ to $\mathrm{P}$ is measured to be 2.32:1, in accordance with that of stoichiometric $\mathrm{Ni}_{12} \mathrm{P}_{5}$. According to $\mathrm{N}_{2}$ adsorption/desorption measurement and the BrunauerEmmett-Teller (BET) analysis, the existence of mesoporous in the $\mathrm{Ni}_{12} \mathrm{P}_{5} @ \mathrm{C} / \mathrm{GNS}$ is observed and the specific surface area is estimated to be about $78.7 \mathrm{~m}^{2} \mathrm{~g}^{-1}$ (Fig. 1d), which is higher than pure $\mathrm{Ni}_{12} \mathrm{P}_{5} @ \mathrm{C}$ of $41.8 \mathrm{~m}^{2} \mathrm{~g}^{-1}$ (Fig. $\mathrm{S} 4 \dagger$ ). Element analysis result shows that the carbon content of $\mathrm{Ni}_{12} \mathrm{P}_{5} @ \mathrm{C} / \mathrm{GNS}$ is $18.15 \%$. The content of $\mathrm{Ni}$ in the $\mathrm{Ni}_{12} \mathrm{P}_{5} @ \mathrm{C} / \mathrm{GNS}$ composite is estimated to be 66.3 wt.\% by ICP instrument. Thus, the weight percentage of $\mathrm{Ni}_{12} \mathrm{P}_{5}$ in the hybrid is about $80.9 \%$. Raman spectrum is employed to investigate the conductivity of carbon of $\mathrm{Ni}_{12} \mathrm{P}_{5} @ \mathrm{C} / \mathrm{GNS}$. As shown in Fig. $\mathrm{S} 5 \dagger$, two strong carbon peaks located at $1346 \mathrm{~cm}^{-1}$ (D-band, $\mathrm{sp}^{3}$-coordinated behavior) 

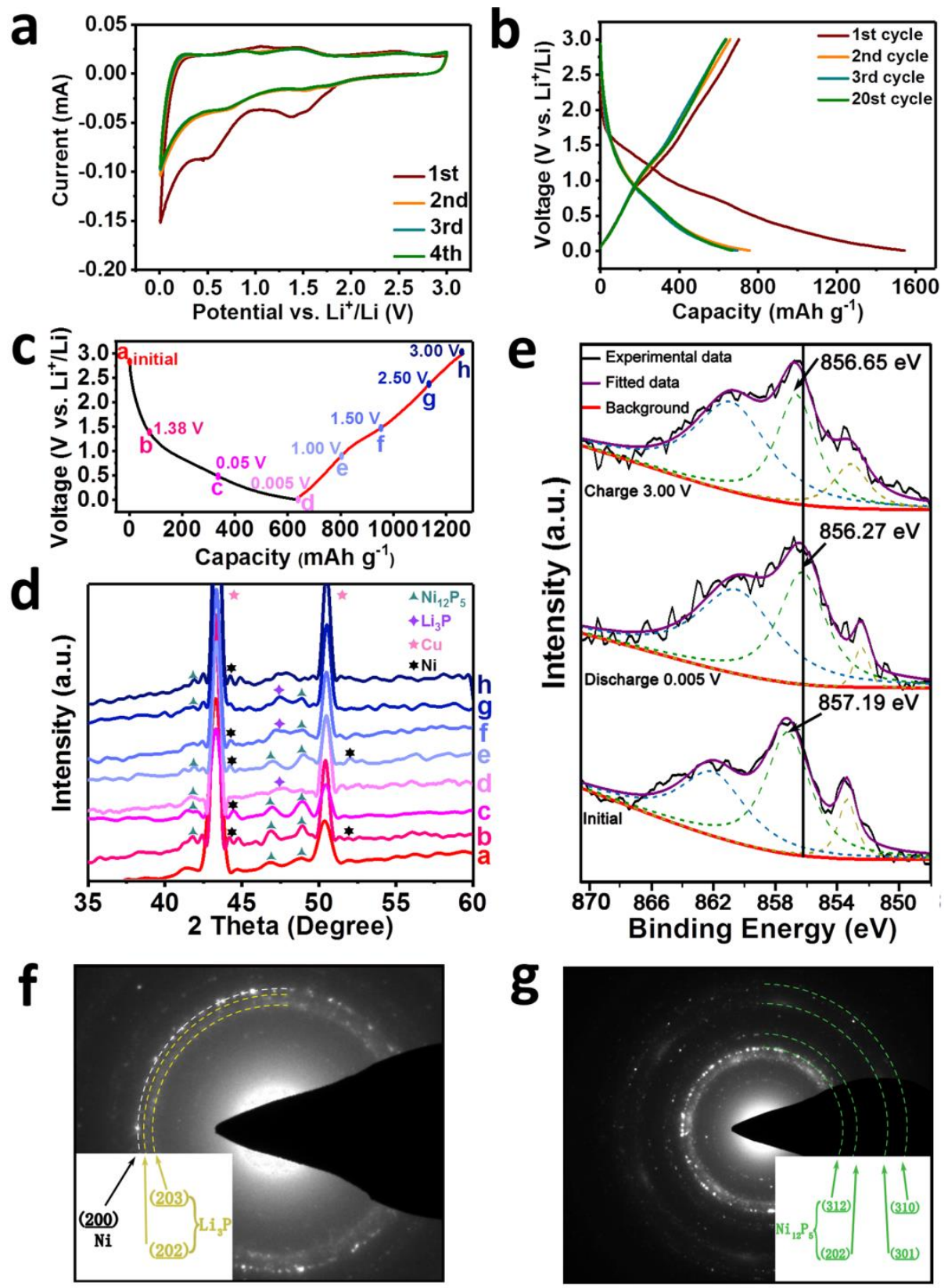

Fig. 3 Electrochemical performances for lithium storage. (a) Cyclic voltammograms of $\mathrm{Ni}_{12} \mathrm{P}_{5} @ C / G N S$ electrode at $0.2 \mathrm{mV} \mathrm{s} \mathrm{s}^{-1}$. (b) Charge/discharge profiles of $\mathrm{Ni}_{12} \mathrm{P}_{5} @ \mathrm{C} / \mathrm{GNS}$ electrode at $100 \mathrm{~mA} \mathrm{~g}^{-1}$. (c) First charge/discharge profile of $\mathrm{Ni}_{12} \mathrm{P}_{5} @ \mathrm{C} / \mathrm{GNS}$ electrode at $100 \mathrm{~mA} \mathrm{~g}^{-1}$. The marked points (from a to $\mathrm{h}$ ) are collected to take XRD tests. (d) Ex situ XRD patterns of Ni ${ }_{12} \mathrm{P}_{5} @ \mathrm{C} / \mathrm{GNS}$ electrode at marked points. (e) XPS patterns of $\mathrm{Ni} 2 \mathrm{p}_{3 / 2}$ in the 10 th cycle, discharge to $0.005 \mathrm{~V}$ and charge to $3.0 \mathrm{~V}$ at a current density of $100 \mathrm{~mA} \mathrm{~g}^{-1}$. (f-g) SAED patterns in the 10 th cycle at a current density of $100 \mathrm{~mA} \mathrm{~g}^{-1}$, discharge to $0.005 \mathrm{~V}$ and charge to $3.00 \mathrm{~V}$.

and $1580 \mathrm{~cm}^{-1}$ (G-band, sp²-hybridized carbon) can apparently be observed. ${ }^{39,40}$ The Raman peak intensity ratio $\left(I_{\mathrm{D}} / I_{\mathrm{G}}=0.78\right)$ is inversely proportional to the graphitization degree of materials, indicating a higher electric conductivity. ${ }^{39}$

The detailed morphology and microstructure of pristine $\mathrm{Ni}_{12} \mathrm{P}_{5} @ \mathrm{C}$ nanocrystals and prepared $\mathrm{Ni}_{12} \mathrm{P}_{5} @ \mathrm{C} / \mathrm{GNS}$ are further characterized by TEM. Low-resolution TEM images show the pure $\mathrm{Ni}_{12} \mathrm{P}_{5} @ \mathrm{C}$ nanocrystals are aggregated with average diameter of $\sim 19 \mathrm{~nm}$ (Fig. 2a, b and S6a $\dagger$ ). The carbon layer thickness is $\sim 3.14 \mathrm{~nm}$. High-resolution TEM (HRTEM) image displays the characteristic lattice fringe spaces of 0.185 and $0.301 \mathrm{~nm}$, which are consistent with the (312) and (220) plants of $\mathrm{Ni}_{12} \mathrm{P}_{5}$ nanocrystal, respectively, demonstrating a high degree of crystallinity (Fig. 2c). Low-magnification TEM images show the hollow structure of carbon-coated product and the particle size distribution histogram displays the $\sim 35 \mathrm{~nm}$ size of $\mathrm{Ni}_{12} \mathrm{P}_{5} @ \mathrm{C} / \mathrm{GNS}$ (Fig. 2d, e and S6b $\dagger$ ). Typical HRTEM image (Fig. 
2f) reveals the $\mathrm{Ni}_{12} \mathrm{P}_{5} @ \mathrm{C}$ anchored on GNS surface is fully hollow and the carbon shell is clear. The carbon layer thickness is $\sim 2.64$ $\mathrm{nm}$ and the thickness of $\mathrm{Ni}_{12} \mathrm{P}_{5}$ is $\sim 6.34 \mathrm{~nm}$. The characteristic lattice fringe spaces of $0.193,0.235$ and $0.217 \mathrm{~nm}$ are consistent with the (312), (330) and (321) plants of $\mathrm{Ni}_{12} \mathrm{P}_{5} @ \mathrm{C}$ nanocrystal, respectively. Meanwhile, the angle between (312) and (330) lattice plane is $53.6^{\circ}$ consistent with the calculation value. Additionally, the crystal type of pure $\mathrm{Ni}_{12} \mathrm{P}_{5} @ \mathrm{C}$ and $\mathrm{Ni}_{12} \mathrm{P}_{5} @ \mathrm{C} / \mathrm{GNS}$ both are polycrystal (Fig. S7 $\dagger$ ). Notably, GNS effectively suppress aggregation of $\mathrm{Ni}_{12} \mathrm{P}_{5} @ \mathrm{C}$ and adjust the growth direction of crystals to construct hollow architecture. The formation mechanism of hollow structure can be ascribed to Kirkendall Effect. It's known that GNS are negatively charged. When dispersed in suspension, the surface functional groups of GNS greatly attract $\mathrm{Ni}^{2+}$, which leads to the faster out-diffusion tendency of inner $\mathrm{Ni}^{2+}$ and forms hollow. ${ }^{41-43}$ The carbon shell derives from the carbonation of OLA. Moreover, the element mapping analysis (Fig. 2g) further clearly confirms the uniform distribution of $\mathrm{C}, \mathrm{Ni}$ and $\mathrm{P}$ elements in the $\mathrm{Ni}_{12} \mathrm{P}_{5} @ \mathrm{C} / \mathrm{GNS}$.

\subsection{Electrochemical performances of LIBs}

Electrochemical Li-storage performances of hollow $\mathrm{Ni}_{12} \mathrm{P}_{5} @ \mathrm{C} / \mathrm{GNS}$ are given in Fig. 3. As shown in Fig. 3a, cyclic voltammetry (CV) is adopted to verify the reversible $\mathrm{Li}^{+}$storage behavior of hollow $\mathrm{Ni}_{12} \mathrm{P}_{5} @ \mathrm{C} / \mathrm{GNS}$. The CV curves display weak redox peaks and box-like shape. This is due to the sorption of lithium ions on the pores and functional groups of GNS surface, as well as the sorption on the edge of defective sites. Thus, the electrochemical behaviors are surface capacitive lithium storage behaviors. ${ }^{44-47}$ In the first cycle, the reduction peaks are located at around 1.5 and $0.7 \mathrm{~V}$, which represent the irreversible structure change, lithiation and formation of solid electrolyte interphase (SEI), respectively. Besides, the oxidation peaks are observed at around 1.0, 1.5 and $2.4 \mathrm{~V}$, which can be severally attributed to the gradual reduction of $\mathrm{Li}_{3} \mathrm{P}$. Subsequently, the curves keep stable in the following cycles implying its high reversibility. According to this mechanism, the reaction process could be summed as:

$$
\mathrm{Ni}_{12} \mathrm{P}_{5}+x \mathrm{Li}^{+}+x \mathrm{e}^{-} \leftrightarrow \mathrm{mLi}_{3} \mathrm{P}+\mathrm{nNi}
$$
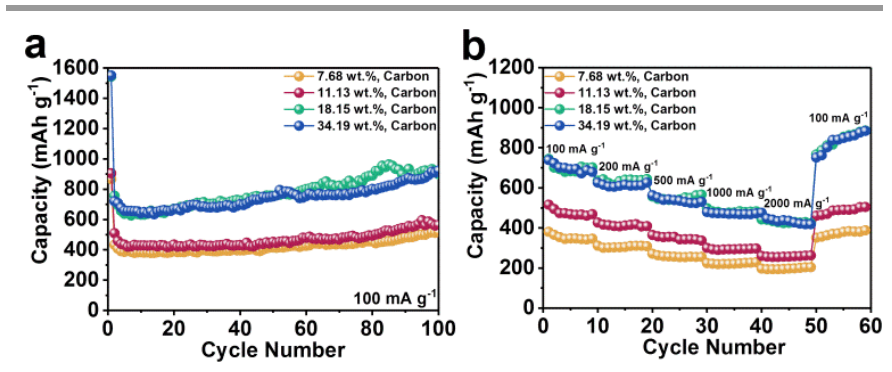

Fig. 4 Electrochemical performances for lithium storage. (a) Cycling performances of $\mathrm{Ni}_{12} \mathrm{P}_{5} @ C / G N S$ with different carbon contents at $100 \mathrm{~mA} \mathrm{~g}^{-1}$ (discharge capacities). (b) Rate performances of $\mathrm{Ni}_{12} \mathrm{P}_{5} @ \mathrm{C} / \mathrm{GNS}$ electrode with different carbon contents at different rate current densities (discharge capacities).
Fig. 3b presents the representative discharge-charge curves of $\mathrm{Ni}_{12} \mathrm{P}_{5} @ \mathrm{C} / \mathrm{GNS}$ at a current density of $100 \mathrm{~mA} \mathrm{~g}{ }^{-1}$, which are consistent with CVs. The initial discharge and charge specific capacities of $\mathrm{Ni}_{12} \mathrm{P}_{5} @ \mathrm{C} / \mathrm{GNS}$ could reach 1543.1 and $702.1 \mathrm{mAh}$ $\mathrm{g}^{-1}$, respectively. It indicates first irreversible losses of about $54.5 \%$, resulting from the irreversible formation of SEI and structure change. However, coulombic efficiency rapidly increases to $86.9 \%$ in the second cycle with the discharge capacity of $756.6 \mathrm{mAh} \mathrm{g}^{-1}$ and charge capacity of $657.5 \mathrm{mAh} \mathrm{g}^{-1}$. Remarkably, the discharge capacity remains at about $668.4 \mathrm{mAh}$ $\mathrm{g}^{-1}$ after 20 cycles at a current rate of $100 \mathrm{~mA} \mathrm{~g}^{-1}$ and its coulombic efficiency remains consistently at $97.14 \%$. To further convince the structure change, ex situ XRD, XPS and selected area electron diffraction (SAED) are employed. Eight different key potentials (Fig. $3 \mathrm{C}$ ) are selected in initial cycle to analyze the phase change. Ex situ XRD (Fig. 3d) shows two obvious transformation. Firstly, the peaks of $\mathrm{Ni}_{12} \mathrm{P}_{5}$ gradually disappear and the peaks of $\mathrm{Li}_{3} \mathrm{P}$ and $\mathrm{Ni}$ appear following the lithiation process. On the contrary, the peaks of $\mathrm{Ni}_{12} \mathrm{P}_{5}$ arise while the peaks of $\mathrm{Li}_{3} \mathrm{P}$ and $\mathrm{Ni}$ fade away during delithiation. This indicates that the lithiation/delithiation of $\mathrm{Ni}_{12} \mathrm{P}_{5} @ \mathrm{C} / \mathrm{GNS}$ is conversion reaction. During discharge process, $\mathrm{Li}^{+}$inset structure of $\mathrm{Ni}_{12} \mathrm{P}_{5}$ forming $\mathrm{Li}_{3} \mathrm{P}$ and $\mathrm{Ni}$. Subsequently, the $\mathrm{Li}_{3} \mathrm{P}$ and $\mathrm{Ni}$ reversibly generate $\mathrm{Ni}_{12} \mathrm{P}_{5}$ in charge process. In addition, XPS spectra study the valence change of $\mathrm{Ni}$ shown in Fig. 3e. The bond energy of $\mathrm{Ni} 2 \mathrm{p}_{2 / 3}$ decrease at $0.005 \mathrm{~V}$ and then increase at $3.00 \mathrm{~V}$, corresponding to the descent and then raise of $\mathrm{Ni}$ valence. Furthermore, SAED patterns (Fig. $3 f$, g) also verify the $\mathrm{Ni}$ and $\mathrm{Li}_{3} \mathrm{P}$ phases in the discharge state and the $\mathrm{Ni}_{12} \mathrm{P}_{5}$ phase in the charge state, which agree well with XRD analysis.
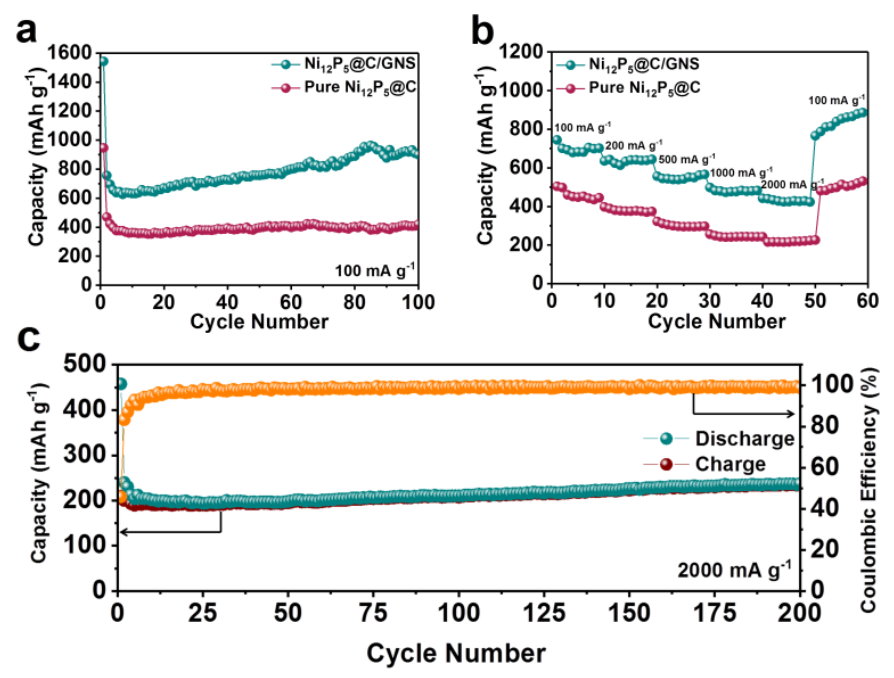

Fig. 5 Electrochemical performances for lithium storage. (a) Cycling performances of pure $\mathrm{Ni}_{12} \mathrm{P}_{5} @ \mathrm{C}$ and $\mathrm{Ni}_{12} \mathrm{P}_{5} @ \mathrm{C} / \mathrm{GNS}$ at $100 \mathrm{~mA} \mathrm{~g}^{-1}$ (discharge capacities). (b) Rate performances of pure $\mathrm{Ni}_{12} \mathrm{P}_{5} @ \mathrm{C}$ and $\mathrm{Ni}_{12} \mathrm{P}_{5} @ \mathrm{C} / \mathrm{GNS}$ electrodes at different rate current densities (discharge capacities). (c) Long-term cycling performances and coulombic efficiency of the $\mathrm{Ni}_{12} \mathrm{P}_{5} @ \mathrm{C} / \mathrm{GNS}$ electrode an $2000 \mathrm{~mA} \mathrm{~g}^{-1}$. 
When considering the performance of a whole electrode, the proportion between $\mathrm{Ni}_{12} \mathrm{P}_{5} @ \mathrm{C}$ and GNS can seriously influence the performances. Broadly speaking, with the increasing of GNS, the electroconductivity of $\mathrm{Ni}_{12} \mathrm{P}_{5} @ C / G N S$ gradually increases. However, the capacity will reach saturation point and not increase any more with the content of GNS increasing. Therefore, in order to explore the best ratio between the active material $\mathrm{Ni}_{12} \mathrm{P}_{5} @ \mathrm{C}$ and GNS, we further prepare four $\mathrm{Ni}_{12} \mathrm{P}_{5} @ \mathrm{C} / \mathrm{GNS}$ composites with different carbon content (7.68, $11.13,18.15$ and $34.19 \mathrm{wt} . \%$, respectively). The carbon contents are characterized by EA. Cycling tests and rate capacities are displayed in Fig. 4. It could be observed that the electrochemical performances of $\mathrm{Ni}_{12} \mathrm{P}_{5} @ \mathrm{C} / \mathrm{GNS}$ electrodes with carbon content above $18.15 \mathrm{wt} . \%$ are superior to that of 11.13 and $7.68 \mathrm{wt} . \%$. The cycling performances of the $\mathrm{Ni}_{12} \mathrm{P}_{5} @ \mathrm{C} / \mathrm{GNS}$ with 7.68, $11.13,18.15$ and 34.19 wt.\% carbon at $100 \mathrm{~mA} \mathrm{~g}^{-1}$ are 517.7, 564.1, 900 and $923 \mathrm{mAh} \mathrm{g}^{-1}$ after 100 cycles, respectively (Fig. 4a). Fig. $4 \mathrm{~b}$ shows the rate capacities of $\mathrm{Ni}_{12} \mathrm{P}_{5} @ \mathrm{C} / \mathrm{GNS}$ with different carbon content. As expected, with the GNS content increasing, the capacities of $\mathrm{Ni}_{12} \mathrm{P}_{5} @ \mathrm{C} / \mathrm{GNS}$ tend to improve, because more GNS offer more ions and electrons transport paths to achieve good performances. However, the capacity of $\mathrm{Ni}_{12} \mathrm{P}_{5} @ \mathrm{C} / \mathrm{GNS}$ no longer infinitely grows with the further increasing of GNS amount. Considering the preparation of GNS is costly and time-consuming, the $\mathrm{Ni}_{12} \mathrm{P}_{5} @ \mathrm{C} / \mathrm{GNS}$ of 18.15 wt. \% carbon is optimum.

Electrochemical lithium storage performances of $\mathrm{Ni}_{12} \mathrm{P}_{5} @ \mathrm{C} / \mathrm{GNS}$ are given in Fig. 5. Fig. 5a displays the cycling performances of the pure $\mathrm{Ni}_{12} \mathrm{P}_{5} @ \mathrm{C}$ and $\mathrm{Ni}_{12} \mathrm{P}_{5} @ \mathrm{C} / \mathrm{GNS}$ at a current density of $100 \mathrm{~mA} \mathrm{~g}^{-1}$. The discharge specific capacity of $\mathrm{Ni}_{12} \mathrm{P}_{5} @ \mathrm{C} / \mathrm{GNS}$ remains at $900 \mathrm{mAh} \mathrm{g}^{-1}$ after 100 cycles much better than that of $\mathrm{Ni}_{12} \mathrm{P}_{5} @ \mathrm{C}\left(420 \mathrm{mAh} \mathrm{g}^{-1}\right)$. The TEM images of $\mathrm{Ni}_{12} \mathrm{P}_{5} @ \mathrm{C} / \mathrm{GNS}$ composite after 100 cycles are shown in Fig. S8 $\dagger$, which shows $\mathrm{Ni}_{12} \mathrm{P}_{5} @ \mathrm{C} / \mathrm{GNS}$ can maintain original appearance and no significant aggregation is observed. The batteries show a gradual gain in capacity. According to previous references, the major reasons can be summarized as the follows: (1) The slow increased capacities are driven by the activation effects. (2) The stabilization process of the SEI layer will result in a gradually increasing capacities. (3) Decreasing polarization and resistances are directly connected to the increase of

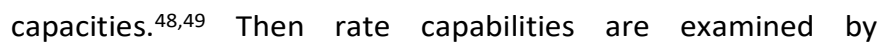
discharging/charging at various current densities (Fig. 5b). $\mathrm{Ni}_{12} \mathrm{P}_{5} @ \mathrm{C} / \mathrm{GNS}$ delivers discharge specific capacities of 702.2, 644.1, 566.5, 482.8, 423.2 and $905.9 \mathrm{mAh} \mathrm{g}^{-1}$ at 100, 200, 500, 1000,2000 and $100 \mathrm{~mA} \mathrm{~g}^{-1}$, respectively, which are much higher than that of pure $\mathrm{Ni}_{12} \mathrm{P}_{5} @ \mathrm{C}$. Moreover, $\mathrm{Ni}_{12} \mathrm{P}_{5} @ \mathrm{C} / \mathrm{GNS}$ can be cycled with high stability at higher current density of $500 \mathrm{~mA} \mathrm{~g}$ ${ }^{1}$ (Fig. S9†) with discharge capacity keeping $308.9 \mathrm{mAh} \mathrm{g}^{-1}$ after 250 cycles and $2 \mathrm{~A} \mathrm{~g}^{-1}$ (Fig. 5c) with the discharge capacity reaching up to $237.3 \mathrm{mAh} \mathrm{g}^{-1}$ after 200 cycles. It firmly verifies their excellent cycling stability and long service life. Table 1 shows the electrochemical performances of the present work for LIBs anode are higher than most of the related reported in seven years. ${ }^{50-59}$
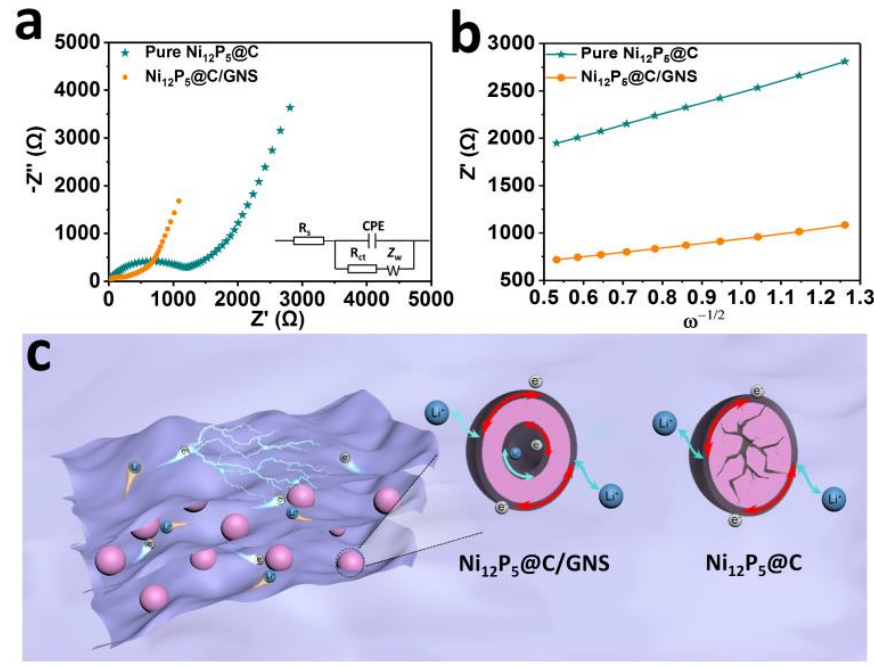

Fig. 6 Electrochemical performances for lithium storage. (a) Nyquist plots of the pure $\mathrm{Ni}_{12} \mathrm{P}_{5} @ \mathrm{C}$ and $\mathrm{Ni}_{12} \mathrm{P}_{5} @ \mathrm{C} / \mathrm{GNS}$ half cells. (b) Real parts of the impedance $\left(Z^{\prime}\right)$ versus the reciprocal square root of the lower angular frequency $(\omega)$ of the pure $\mathrm{Ni}_{12} \mathrm{P}_{5} @ C$ and $\mathrm{Ni}_{12} \mathrm{P}_{5} @ \mathrm{C} / \mathrm{GNS}$. (c) Schematic diagram of electron/ion transportation in the special $\mathrm{Ni}_{12} \mathrm{P}_{5} @ \mathrm{C} / \mathrm{GNS}$ composite vs. pure $\mathrm{Ni}_{12} \mathrm{P}_{5} @ \mathrm{C}$ nanocrystals.

Electrochemical impedance spectroscopy (Fig. 6a) demonstrates that $\mathrm{Ni}_{12} \mathrm{P}_{5} @ \mathrm{C} / \mathrm{GNS}$ shows a lower charge transfer resistance (279.3 $\Omega$, fitted by Zview) than pure $\mathrm{Ni}_{12} \mathrm{P}_{5} @ \mathrm{C}(1021.0 \Omega)$. The ion diffusion capabilities of electrodes are estimated according to the slope of the lines between $Z^{\prime}$ and $\omega^{-1 / 2}(\sigma$, the value of which represents Warburg factor, Fig. $6 b$ ). Because $\sigma^{2}$ is in inverse ratio to the diffusion coefficient of $\mathrm{Na}^{+}$ ions $\left(D_{\mathrm{Na}}\right) .^{60}$ It indicates that the $\mathrm{D}_{\mathrm{Na}}$ of $\mathrm{Ni}_{12} \mathrm{P}_{5} @ \mathrm{C} / \mathrm{GNS}$ is higher than that of pure $\mathrm{Ni}_{12} \mathrm{P}_{5} @ \mathrm{C}$. These results declare the cathode and $\mathrm{Ni}_{12} \mathrm{P}_{5} @ \mathrm{C} / \mathrm{GNS}$ anode at $100 \mathrm{~mA} \mathrm{~g}^{-1}$ (inset is digital picture of a full cell that lights LEDs). $\mathrm{Ni}_{12} \mathrm{P}_{5} @ \mathrm{C} / \mathrm{GNS}$ electrode performs superior electronic/ionic conductivity, which could be reasonably attributed to two merits (Fig. 6c). (1) Hollow nanocrystal structure shortens ion transport path and provides ample room to accommodate the volume expansion, so that the cycling performance is improved drastically. (2) Carbon shell and adding of GNS
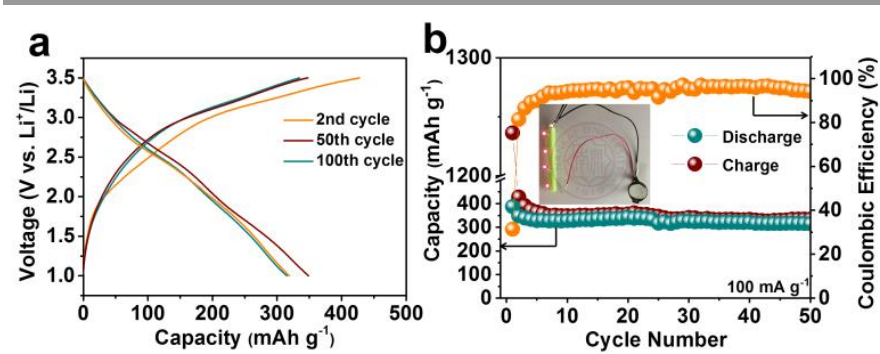

Fig. 7 Electrochemical performances for lithium storage. (a) Charge/discharge profiles and (b) Cycling performance of the full cell coupled by $\mathrm{LiCoO}_{2}$. 
Table 1 Comparison of cycling performances of some TMPs materials for LIBs anodes.

\begin{tabular}{|c|c|c|c|c|c|}
\hline Material description & Preparation strategy & $\begin{array}{l}\text { Current density } \\
\qquad\left(\mathrm{mA} \mathrm{g}^{-1}\right)\end{array}$ & Cycle number & $\begin{array}{l}\text { Discharge capacity } \\
\qquad\left(\mathrm{mAh} \mathrm{g}^{-1}\right)\end{array}$ & Ref. \\
\hline Nano porous $\mathrm{NiO}$-capped $\mathrm{Ni}_{3} \mathrm{P}$ & Electroless plating process & 38.8 & 60 & $\sim 558$ & 50 \\
\hline $\mathrm{Ni}_{2} \mathrm{P}$ nanorods on nickel foam & $\begin{array}{l}\text { Hydrothermal method and } \\
\text { solid state reaction }\end{array}$ & 50 & 100 & $\sim 507$ & 51 \\
\hline Hierarchical $\mathrm{Ni}_{2} \mathrm{P}$ spheres & One-pot reaction & 271 & 50 & $\sim 365.3$ & 52 \\
\hline Peapod-like $\mathrm{Ni}_{2} \mathrm{P} / \mathrm{C}$ & Hydrothermal method & 100 & 200 & $\sim 630$ & 53 \\
\hline Graphene/ $/ \mathrm{Ni}_{2} \mathrm{P}$ & Hydrothermal method & 300 & 500 & $\sim 457$ & 54 \\
\hline $\mathrm{Ni}_{5} \mathrm{P}_{4} @ \mathrm{C}$ nanoparticles & Solid state reaction & 180 & 100 & $\sim 600$ & 55 \\
\hline $\mathrm{Ni}_{5} \mathrm{P}_{4} @ \mathrm{C}$ composite & $\begin{array}{l}\text { Wet chemistry reaction } \\
\text { and solid state reaction }\end{array}$ & 73 & 50 & $\sim 644.1$ & 56 \\
\hline Nanostructured $\mathrm{NiP}_{2} @ \mathrm{C}$ & Solid state reaction & 50 & 50 & $\sim 656$ & 57 \\
\hline $\mathrm{Ni}_{12} \mathrm{P}_{5} / \mathrm{CNT}$ nanohybrids & $\begin{array}{l}\text { One-pot hot-solution } \\
\text { colloidal synthetic }\end{array}$ & 100 & 100 & $\sim 665$ & 58 \\
\hline Peapod-like $\mathrm{Ni}_{12} \mathrm{P}_{5} / \mathrm{C}$ & Solvothermal method & 100 & 100 & $\sim 600$ & 59 \\
\hline \multirow[t]{3}{*}{ Our work } & Refluxing method & 100 & 100 & $\sim 900$ & \\
\hline & & 500 & 250 & $\sim 308.9$ & \\
\hline & & 2000 & 200 & $\sim 237.3$ & \\
\hline
\end{tabular}

effectively prevent the agglomeration between nanocrystals and improve the electronic conductivity of $\mathrm{Ni}_{12} \mathrm{P}_{5} @ \mathrm{C}$ accelerating the transmission of electron, which greatly elevate the rate capacities. Thus, the designed $\mathrm{Ni}_{12} \mathrm{P}_{5} @ \mathrm{C} / \mathrm{GNS}$ exhibits excellent cycling performance and outstanding rate capability, indicating its overwhelming superiority in applications.

We also further test the full battery cycling performances with prepared $\mathrm{Ni}_{12} \mathrm{P}_{5} @ \mathrm{C} / \mathrm{GNS}$ as anode and commercial $\mathrm{LiCoO}_{2}$ as cathode. Fig. 7a displays the galvanostatic charge/discharge curves of the full LIBs at $100 \mathrm{~mA} \mathrm{~g}^{-1}$. The reversible specific capacity (based on the anode material) can reach $350 \mathrm{mAh} \mathrm{g}^{-1}$ and the average working voltage is about $2.3 \mathrm{~V}$. What's more, the curves overlap well in the process of 50 to 100 cycles, which reveals the high reversibility and stability of the LiCoO $2 / / \mathrm{Ni}_{12} \mathrm{P}_{5} @ \mathrm{C} / \mathrm{GNS}$ full cell. Fig. 7b shows the stable capacity of $315.1 \mathrm{mAh} \mathrm{g}^{-1}$ can be achieved at the current density of $100 \mathrm{~mA} \mathrm{~g}^{-1}$ after 50 cycles. To demonstrate its potential application, the full cell is used to light up red LED
(Fig. 7b, inset).

\subsection{Electrochemical performances of SIBs}

As mentioned before, the $\mathrm{Ni}_{12} \mathrm{P}_{5} @ \mathrm{C} / \mathrm{GNS}$ electrode will also show promising electrochemical performances for sodium-ion storage in half cells. Fig. 8a shows the charge and discharge capacities are 212.7 and $234.9 \mathrm{mAh} \mathrm{g}^{-1}$ of 5 th cycle at $100 \mathrm{~mA}$ $\mathrm{g}^{-1}$, respectively. Remarkably, the $\mathrm{Ni}_{12} \mathrm{P}_{5} @ \mathrm{C} / \mathrm{GNS}$ electrode shows a stable cycling performance (Fig. 8b). After 500 cycles, the discharge capacity remains $164.8 \mathrm{mAh} \mathrm{g}^{-1}$. Fig. 8c exhibits the rate performances of the $\mathrm{Ni}_{12} \mathrm{P}_{5} @ \mathrm{C} / \mathrm{GNS}$ electrode. The reversible capacities are 171.6, 162.4, 144.4, 126.8, 110 and $105.6 \mathrm{mAh} \mathrm{g}^{-1}$ for current densities of 50, 100, 200, 500, 1000 and $2000 \mathrm{~mA} \mathrm{~g}^{-1}$, respectively. More importantly, the capacity can restore $199.2 \mathrm{mAh} \mathrm{g}^{-1}$ when the current density returns to $100 \mathrm{~mA} \mathrm{~g}^{-1}$, implying their high current adaptation. Since $\mathrm{Na}^{+}$ $(1.02 \AA)$ is heavier and larger than that of $\mathrm{Li}^{+}(0.76 \AA)$, leading to the inferior reaction dynamics of $\mathrm{Na}^{+}$. This significantly influences the electrochemical performances of $\mathrm{Ni}_{12} \mathrm{P}_{5} @ \mathrm{C} / \mathrm{GNS}$ electrode in $\mathrm{Na}^{+}$storage resulting in the lower capacity and 
a
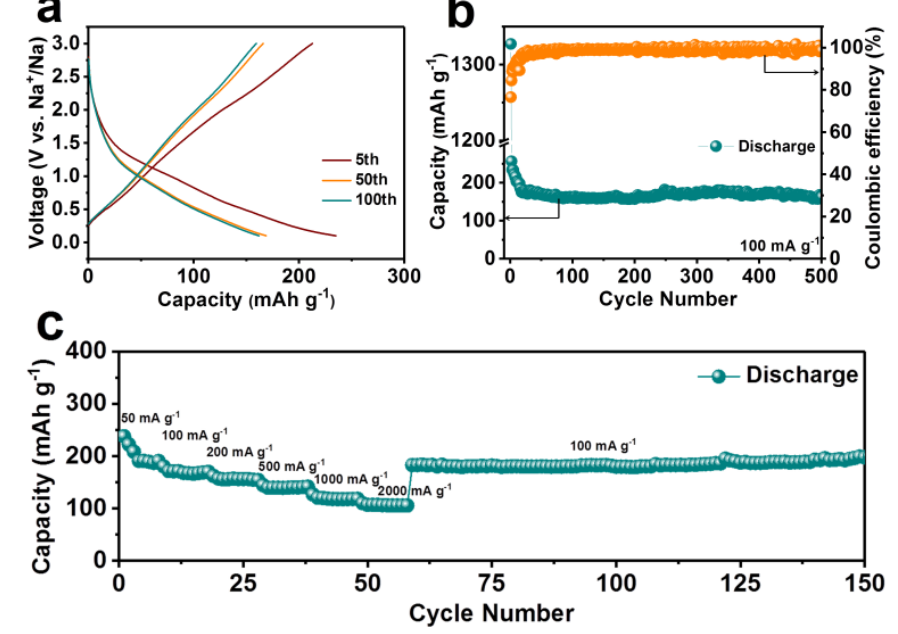

Fig. 8 Electrochemical performances for sodium storage. (a) Charge/discharge profiles of the $\mathrm{Ni}_{12} \mathrm{P}_{5} @ \mathrm{C} / \mathrm{GNS}$ electrode at $100 \mathrm{~mA} \mathrm{~g}^{-1}$. (b) Cycling performance of the $\mathrm{Ni}_{12} \mathrm{P}_{5} @ \mathrm{C} / \mathrm{GNS}$ at $100 \mathrm{~mA} \mathrm{~g}^{-1}$. (c) Rate performance of the $\mathrm{Ni}_{12} \mathrm{P}_{5} @ \mathrm{C} / \mathrm{GNS}$ electrode at different rate current densities.

poor stability. Therefore, further studies should be developed to improve its sodium storage properties with some novel strategies.

\section{Conclusions}

In summary, the hollow $\mathrm{Ni}_{12} \mathrm{P}_{5} @ \mathrm{C} / \mathrm{GNS}$ composite is firstly prepared by a simple refluxing method. The $\mathrm{Ni}_{12} \mathrm{P}_{5} @ \mathrm{C}$ nanocrystals with particularly hollow structure and thin carbon shell are anchored on the GNS. This architecture combines the advantages of hollow structure and high electric GNS microstructure revealing excellent electrochemical performances at LIBs and SIBs in terms of cycle stability and rate capability. As an anode for LIBs, it displays an excellent special capacity of $900 \mathrm{mAh} \mathrm{g}^{-1}$ at a current density of $100 \mathrm{~mA} \mathrm{~g}^{-1}$ after 100 cycles, and high rate capability of special capabilities of 702.2, 644.1, 566.5, 482.8, 423.2 and 905.9 $\mathrm{mAh} \mathrm{g}^{-1}$ at 100, 200, 500, 1000, 2000 and $100 \mathrm{~mA} \mathrm{~g}^{-1}$, respectively. As for Na-ion storage, this hollow $\mathrm{Ni}_{12} \mathrm{P}_{5} @ \mathrm{C} / \mathrm{GNS}$ composite also maintains a reversible capacity of approximate $235 \mathrm{mAh} \mathrm{g}^{-1}$ at $100 \mathrm{~mA} \mathrm{~g}^{-1}$. These promising features make hollow $\mathrm{Ni}_{12} \mathrm{P}_{5} @ \mathrm{C} / \mathrm{GNS}$ ideal candidate for the next generation of battery material and can be extended to electrochemical applications in various fields, such as fuel cells, super capacitors, electrochemical sensors, and so forth.

\section{Acknowledgements}

This work was financially supported by MOST (2016YFA0202500), NSFC (51471089, 51501072), MOE (IRT13R30), NSFT (17JCYBJC17900); and 111 Project (B12015).

\section{Notes and references}

1 L. Shi, T. S. Zhao, J. Mater. Chem. A, 2017, 5, 3735.

2 A. Devaraj, M. Gu, R. Colby, P. Yan, C. M. Wang, J. M. Zheng, J. Xiao, A. Genc, J. G. Zhang, I. Belharouak, D. Wang, K. Amine, S. Thevuthasan, Nat. Commun., 2015, 6, 8014.

3 W. H. Zuo, W. H. Zhu, D. F. Zhao, Y. F. Sun, Y. Y. Li, J. P. Liu, X. W. Lou, Energy Environ. Sci., 2016, 9, 2881.

4 G. Q. Xu, P. Liu, Y. R. Ren, X. B. Huang, Z. G. Peng, Y. G. Tang, H. Y. Wang, J. Power Sources, 2017, 361, 1.

5 X. X. Zuo, J. Zhu, P. M. Buschbaum, Y. J. Cheng, Nano Energy, 2017, 31, 113.

6 Y. Zhao, Y. Zhang, H. Sun, X. L. Dong, J. Y. Cao, L. Wang, Y. F. Xu, J. Ren, Y. HWang, I. H. Son, X. L. Huang, Y. G. Wang, H. S. Peng, Angew. Chem. Int. Ed., 2016, 55, 14384.

7 C. C. Chen, J. B. Wang, Q. Zhao, Y. J. Wang, J. Chen, ACS Energy Letters, 2016, 1, 1165.

8 D. Sun, Y. G. Tang, D. L. Ye, J. Yan, H. S. Zhou, H. Y. Wang, ACS Appl. Mater. Interfaces, 2017, 9, 5254.

9 F. Mueller, N. Loeffler, G. T. Kim, T. Diemant, R. J. Behm, S. Passerini, ChemSusChem, 2016, 9, 1290.

10 H. N. He, D. Sun, Q. Zhang, F. Fu, Y. G. Tang, J. Guo, M. H. Shao, H. Y. Wang, ACS Appl. Mater. Interfaces, 2017, 9, 6093.

11 Y. Liu, J. Y. Liu, M. Y. Hou, L. Fan, Y. G. Wang, Y. Y. Xia, J. Mater. Chem. A, 2017, 5, 10902.

12 H. C. Gao, W. D. Zhou, K. Park, J. B. Goodenough, Adv. Energy Mater., 2016, 6, 1600467.

13 H. N. He, H. Y. Wang, D. Sun, M. H. Shao, X. B. Huang, Y. G. Tang, Electrochim. Acta, 2017, 236, 43.

14 H. N. He, Q. Zhang, H. Y. Wang, H. H. Zhang, J. D. Li, Z. G. Peng, Y. G. Tang, M. H. Shao, J. Power Sources, 2017, 354, 179.

15 J. Y. Li, X. L. Wu, X. H. Zhang, H. Y. Lü, G. Wang, J. Z. Guo, F. Wan, R. S. Wang, Chem. Commun., 2015, 51, 14848.

16 X. P. Han, F. Y. Cheng, C. C. Chen, F. J. Li, J. Chen, Inorg. Chem. Front., 2016, 3, 866-871.

17 F. Niu, J. Yang, N. N. Wang, D. P. Zhang, W. L. Fan, J. Yang, Y. T. Qian, Adv. Funct. Mater., 2017, 27, 1700522.

18 J. Liu, P. Kopold, C. Wu, P. A. V. Aken, J. Maier, Y. Yu, Energy Environ. Sci., 2015, 8, 3531.

19 C. C. Chen, Y. Y. Dong, S. Y. Li, Z. H. Jiang, Y. J. Wang, L. F. Jiao, H. T. Yuan, J. Power Sources, 2016, 320, 20.

20 J. Peters, D. Buchholz, S. Passerini, M. Weil, Energy Environ. Sci., 2016, 9, 1744.

21 Y. W. Tan, H. Wang, P. Liu, C. Cheng, F. Zhu, A. Hirata, M. W. Chen, Adv. Mater., 2016, 28, 2951-2955.

22 Y. Feng, X. Y. Yu, U. Paik, Chem. Commun., 2016, 52, 16331636.

23 M. Sun, H. J. Liu, J. H. Qu, J. H. Li, Adv. Energy Mater., 2016, 6, 1600087.

24 J. W. Zhou, J. Qin, L. C. Guo, N. Q. Zhao, C. S. Shi, E. Z. Liu, F. He, L. Y. Ma, J. J. Li, C. N. He, J. Mater. Chem. A, 2016, 4, 1737017380.

25 G. L. Guo, Y. Y. Guo, H. T. Tan, H. Yu, W. H. Chen, E. Fong, Q. Y. Yan, J. Mater. Chem. A, 2016, 4, 10893-10899.

26 E. J. Sheets, R. B. Balow, W. C. Yang, E. A. Stach, R. Agrawal, Nanoscale, 2015, 7, 19317-19323.

27 F. P. Zhao, N. Han, W. J. Huang, J. J. Li, H. L. Ye, F. J. Chen, Y. G. Li, J. Mater. Chem. A, 2015, 3, 21754-21759.

28 J. F. Qian, Y. Xiong, Y. L. Cao, X. P. Ai, H. X. Yang, Nano Lett., 2014, 14, 1865-1869.

29 Q. S. Xie, D. Q. Zeng, P. Y. Gong, J. Huang, Y. T. Ma, L. S. Wang, D. L. Peng, Electrochim. Acta, 2017, 232, 465-473.

30 Y. H. Cui, M. Z. Xue, Z. W. Fu, X. L. Wang, X. J. Liu, J. Alloys Comp., 2013, 555, 283-290.

31 X. S. Zhou, L. Yu, X. W. Lou, Adv. Energy Mater., 2016, 6, 1600451. 
32 Q. L. Wei, Y. N. Xu, Q. D. Li, S. S. Tan, W. H. Ren, Q. Y. An, L. Q. Mai, Chem. Commun., 2016, 52, 8730-8732.

33 Y. Y. Lu, P. F. Zhou, K. X. Lei, Q. Zhao, Z. L. Tao, J. Chen, Adv. Energy Mater., 2017, 7, 1601973.

34 Y. Kim, Y. Kim, A. Choi, S. Woo, D. Mok, N. S. Choi, Y. S. Jung, J. H. Ryu, S. M. Oh, K. T. Lee, Adv. Mater., 2014, 26, 4139-4144.

35 A. Ueda, M. Nagao, A. Inoue, A. Hayashi, Y. Seino, T. Ota, M. Tatsumisago, J. Power Sources, 2013, 244, 597-600.

36 Z. Q. Li, L. Y. Zhang, X. L. Ge, C. X. Li, S. H. Dong, C. X. Wang, L. W. Yin, Nano Energy, 2017, 32, 495-502.

37 C. Y. Peng, L. Kang, S. Cao, Y. Chen, Z. S. Lin, W. F. Fu, Angew. Chem. Int. Ed., 2015, 54, 15725-15729.

38 A. Alazmi, O. E. Tall, S. Rasul, M. N. Hedhili, S. P. Patole, P. M. J. Costa, Nanoscale, 2016, 8, 17783-17787.

39 Y. J. Fang, L. F. Xiao, X. P. Ai, H. X. Yang, Adv. Mater., 2015, 27, 5895-5900.

40 E. H. Wang, W. Xiang, R. Rajagopalan, Z. G. Wu, J. Yang, M. Z. Chen, B. H. Zhong, S. X. Dou, S. L. Chou, X. D. Guo, Y. M. Kang, J. Mater. Chem. A, 2017, 5, 9833.

41 G. D. Park, J. S. Cho, Y. C. Kang, Nanoscale, 2015, 7, 1678116788.

42 J. W. Wang, A. C. J. Peck, J. B. Tracy, Chem. Mater., 2009, 21, $4462-4467$

43 M. Lin, B. L. Chen, X. Wu, J. S. Qian, L. F. Fei, W. Lu, L. W. H. Chan, J. K. Yuan, Nanoscale, 2016, 8, 1856-1860.

44 C. J. Chen, Y. W. Wen, X. L. Hu, X. L. Ji, M. Y. Yan, L. Q. Mai, P. Hu, B. Shan, Y. H. Huang, Nat. Commun., 2015, 6, 6929.

45 C. J. Chen, Z. G. Wang, B. Zhang, L. Miao, J. Cai, L. F. Peng, Y. Y. Huang, J. J. Jiang, Y. H. Huang, L. N. Zhang, J. Xie, Energy Storage Mater., 2017, 8, 161-168.

46 C. J. Chen, H. H. Xu, T. F. Zhou, Z. P. Guo, L. N. Chen, M. Y. Yan, L. Q. Mai, P. Hu, S. J. Cheng, Y. H. Huang, J. Xie, Adv. Energy Mater., 2016, 6, 1600322.

47 M. J. Lu, W. H. Yu, J. Shi, W. Liu, S. G. Chen, X. Wang, H. L. Wang, Electrochim. Acta, 2017, 251, 396-406.

48 L. F. Zhang, W. J. He, M. Ling, K. C. Shen, Y. Liu, S. W. Guo, Electrochim. Acta, 2017, 252, 322-330.

49 C. L. Sun, M. Z. Yang, T. L. Wang, Y. L. Shao, Y. Z. Wu, X. P. Hao, ACS Appl. Mater. Interfaces, 2017, 9, 26631-26636.

50 J. H. Hu, P. Wang, P. P. Liu, G. Q. Cao, Q. Wang, M. Wei, J. Mao, C. H. Liang, G. S. Shao, Electrochim. Acta, 2016, 220, 258-266.

51 Q. Li, J. J. Ma, H. J. Wang, X. Yang, R. Yuan, Y. Q. Chai, Electrochim. Acta, 2016, 213, 201-206.

52 Y. Lu, J. P. Tu, J. Y. Xiang, X. L. Wang, J. Zhang, Y. J. Mai, S. X. Mao, J. Phys. Chem. C, 2011, 115, 23760-23767.

53 Y. J. Bai, H. J. Zhang, X. Li, L. Liu, H. T. Xu, H. J. Qiu, Y. Wang, Nanoscale, 2015, 7, 1446-1453.

54 C. Wu, P. Kopold, P. A. V. Aken, J. Maier, Y. Yu, Adv. Mater., 2017, 29, 1604015.

55 J. Jiang, C. D. Wang, W. Li, Q. Yang, J. Mater. Chem. A, 2015, 3, 23345-23351.

56 Y. Lu, J. P. Tu, Q. Q. Xiong, J. Y. Xiang, Y. J. Mai, J. Zhang, Y. Q. Qiao, X. L. Wang, C. D. Gu, S. X. Mao, Adv. Funct. Mater., 2012, 22, 3927-3935.

57 G. H. Li, H. Yang, F. C. Li, J. Du, W. Shi, P. Cheng, J. Mater. Chem. A, 2016, 4, 9593-9599.

58 C. D. Wang, T. Ding, Y. Sun, X. L. Zhou, Y. Liu, Q. Yang, Nanoscale, 2015, 7, 19241-19249.

59 H. J. Zhang, Y. Y. Feng, Y. Zhang, L. Fang, W. X. Li, Q. Liu, K. Wu, Y. Wang, ChemSusChem, 2014, 7, 2000-2006.

60 Y. C. Liu, N. Zhang, H. Y. Kang, M. H. Shang, L. F. Jiao, J. Chen, Chem. Eur. J., 2015, 21, 11882. 